\title{
Implementation of Graduates Standard Competency Test in Universitas Negeri Medan
}

\author{
Jamalum Purba $^{1}$, Budi Ali Mukmin ${ }^{2}$, Tiur Malasari Siregar ${ }^{3}$ \\ \{jp64.purba@gmail.com¹, bamsarumpaet@gmail.com2, tiurmalasarinew2019@gmail.com3\} \\ ${ }^{1}$ Chemistry Study Program, Universitas Negeri Medan, Indonesia \\ ${ }^{2}$ Citizenship Education Study Program, Universitas Negeri Medan, Indonesia \\ ${ }^{3}$ Mathematics Study Program, Universitas Negeri Medan, Indonesia
}

\begin{abstract}
The purpose of this research is to describe the results of the implementation of the Standard Competency Test for Graduates in the Universitas Negeri Medan. The standardized tests provided include tests of learning innovation models, statistical tests and ICT tests. The method used in this research is the descriptive method. This research was conducted by observing the implementation of standardized test exams given to students of Medan State University who had completed their studies. The results in this research then become information and considerations in evaluating the implementation of standardized tests at Medan State University. The results of this research indicate that the implementation of the standard competency test for graduates at Universitas Negeri Medan runs under predetermined procedures.
\end{abstract}

Keywords: standardized tests

\section{Introduction}

Education is a place of the learning process. Whether it is learning knowledge, skills, and habits. According to Undang-Undang Nomor 20 Tahun 2003 [1], Education is a conscious and planned effort to create a learning atmosphere and learning process so that students actively develop their potential to have religious-spiritual strength, self-control, personality, intelligence, noble character, and the skills needed by himself, society, people and nation. Based on the descriptions, it is clear the importance of education.

Evaluation is an identification process to measure/assess whether an activity or program carried out under the planning or objectives to be achieved. One of the objectives of the evaluation is to find out the level of one's mastery of the competencies that have been set. Where what is meant by competence based on the Kamus Besar Bahasa Indonesia (KBBI) is who has the ability. Competence is a skill, attitude, and knowledge that can be reflected in the mindset and actions that continue to develop dynamically and continuously at all times. Therefore, an evaluation is needed to see someone's competence in their educations.

Furthermore, given the purpose of the evaluation in seeing its competence, it is necessary to hold a competency test that has standards. In this research used a standard HOTS-based test that has been previously validated. Precisely in 2018, Universitas Negeri Medan has developed standardized test questions based on High Order Thinking Skills (HOTS)[2]. HOTS-based questions are used to align with the requirements of the curriculum currently being used at UNIMED, the Indonesian National Qualification Framework (KKNI). Where 
learning outcomes must go to internalization and gather knowledge, knowledge, practical knowledge, skills, affections, and competencies needed through a structured educational process and cover the specific fields of science/expertise or through work experience.

The standardized test referred to in this study is a test that assesses the ability/expertise that should be possessed by students before students graduate from Universitas Negeri Medan to compete in jobs or others. Universitas Negeri Medan has conducted a graduate competency test in the form of a standardized test. This standardized test is given to students who have met the standardized test requirements.

\section{Research method}

The method used in this research is the descriptive method. According to Sugiyono [3] the definition of the research method is as follows: "the research method can be interpreted as a scientific way to get valid data with the aim to be found, developed, and proven, a certain knowledge so that in turn it can be used to understand, solve and anticipate problems". With this method, the authors intend to collect historical data and observe certain aspects relating to the problem being investigated by the author so the data that will support the preparation of research reports can be obtained. The data obtained are then processed and analyzed further based on the theory that has been studied so that it obtains an illustration of the object and conclusions can be drawn about the problem under research.

The object of research investigated by the author is the implementation of the standard competency test of graduates at Universitas Negeri Medan. The approach used is descriptive. According to Sugiyono[4] the definition of descriptive is: "descriptive research is research conducted to determine the existence of an independent variable, either only on one or more variables without making comparisons or connecting with other variables (the independent variable is a stand-alone variable, not an independent variable, because if the independent variable is always paired with the dependent variable".

In this research, a descriptive approach will be used to identify and explain the procedures for implementing standard competency tests for graduates in Universitas Negeri Medan. The target population is students who will complete their studies from Universitas Negeri Medan. A research instrument is a tool used to collect data in a study. The research is to measure the social phenomena, so in this research, there should be an appropriate tool. The instruments used in this research were observation sheets, interviews, and questionnaires.

\section{Result and discussion}

The implementation of the standard competency test for graduates at Universitas Negeri Medan has been around for the past 10 years. From year to year, the implementation continues to have better chances and better organized. For example, at the beginning of the implementation of this standard test students had to come to the Computer Center (Pusat Komputer, PUSKOM) or now known as the Unit Pelaksana Teknis Teknologi Informasi dan Komunikasi (UPT TIK) as early as possible to get the exam numbers. But now this has changed. Everything related to standardized tests is online. To register, students can simply open the web address that has been provided.

The purpose of this test is to standardize the ability of students who will graduate or complete their studies at Universitas Negeri Medan. This standard test consists of three (3) 
aspects, namely the learning innovation model tests, statistical tests, and ICT tests. All students who have met the requirements must take this standard test. Implementation of this standard test has certain procedures and requirements to follow.

The registration requirements for taking this standard test are described as follows: (1) participants are students/alumni of Universitas Negeri Medan, (2) have completed the Course Credit load of 114/118 SKS for the D-3 level and 144 SKS for the S-1 level. In this case, the data has been integrated with Academic, (3) softcopy of passport photo at registration with a maximum photo file size of $200 \mathrm{~KB}$. Furthermore, registration procedures included: (1) for students who meet the standardized test requirements above, please register via online on the page http://bak.unimed.ac.id Enter via the Standard Test menu or on the page http://exam.unimed.ac.id, (2) login using Student's ID and Password (make sure you've changed the password) used to access the web http://akad.unimed.ac.id, (3) match the data available, then click the Standardized Test Exam List button (make sure the button disappears after clicking). Students who repeat are required to re-register by clicking on the Standardized Remedial Test Register button.

TATA CARA PENDAFTARAN TES STANDAR PERIODE WISUDA AGUSTUS 2019

PERSYARATAN PENDAFTARAN :

1. Peserta adalah mahasiswa/alumi Universitas Negeri Medan.

2. Telah menyelesaikan beban SKS scbanyak $114 / 118$ SKS jenjang D-3 dan 144 SKS jenjang

S1 (data terintegrasi denzan Akademik).

3. Soffcopy Pas Foto saat pendattaran (ukuran file foto maks $200 \mathrm{~KB}$ )

ALUR PENDAFT ARAX

1. Bagi mahasiswa yang memenuhi persyaratan tes standar di atas, silahkan mendaftarkan diri secara online di laman hutn:/bak-unimed acid masuk via menu Tes Standar atau laman http://exam.umimed ac.id.

2. login menggunakan NIM dan Password (pastikan sudah pernah mengenati password) yang digunakan untuk mengakses web htp://ukad.unimed.ac.id.

3. Cocokkan data yang tersedia, kemudian klik tombol Daftar Ljian Tes Standar (pastikan tombol hilang seteiah di $k 7 j$ ). Bari mahasiswa yang menculang diwajibkan mendaflar ulang dengan klik tombal Daftar Remedial Tes Standar

CATATAN:

Informasi jadwal ujian dan hasil ujian dapat dilihat di laman Tes Standar laman http://exam.unimed.acid

2. Mata ujian:

- Program studi Kependidikan : ICT, Statistik \& Inovasi Model Pembelajaran.

- Program studi NonKependidikan : ICT dan Statistik.

3. Bagi peserta yang mendaftar diluar jadwal pendaftaran, direkomendasikan untuk mengikuti tes standar periode berikutrya.

DRAFT JADWAL TES ST ANDAR PERIODE WISUDA AGUSTUS 2019

\begin{tabular}{|c|c|c|}
\hline Nama Kegiatan & I.akasi & Tanggal \\
\hline Sosialisasi & Fakultas \& Website & 01 s.d. 07 Agenstus 2019 \\
\hline Daftar Online & Website E vam UNTMED & 01 s.d. 07 Agustus 2019 \\
\hline Ujiau Utama I & A.B.C\&D & 08 \& 09 Aqustus 2019 \\
\hline Ujian Utamun II & $A, B, C \& D$ & $12 \& 13$ Agustus 2019 \\
\hline Remedial Wisuda Juni 2018 & $A, B, C \& D$ & Dikendisikan di Utama \\
\hline Remedial Kolektif 1 & A.B.C\&D & 15 \& 16 Aqustus 2019 \\
\hline Remedial Kolektif II & A, B, C\&D & $22 \& 23$ Agustus 2019 \\
\hline $\begin{array}{l}\text { tan Tambahan: } \\
\text { Lokas: } \\
\text { A : FMIPA - GEDUNG } \\
\text { B : FT - GEDUNG } 071 \\
\text { C : TIK - GEDUNO 25 } \\
\text { D : FBS - GEDUNG } 70\end{array}$ & $\begin{array}{l}\text { TII LAB MATEMATIKA } \\
\text { LAB KOMPUTER FT } \\
\text { LAB KOMPUIER I/2 } \\
\text { IAB MULTMEDLA }\end{array}$ & $201 / 202$ \\
\hline
\end{tabular}

Fig.1. Registration Procedures for Standards Tests 
The picture above is the procedure for registration that must be followed by standardized test-takers. This means, there is an official explanation regarding the registration of standardized tests so that it does not confuse students. After students get their exam numbers, students come according to a predetermined schedule. The implementation of this standardized test is divided into two, the first for students with education majors and the second for non-educational majors.

The number of standardized test questions at the beginning of the holding of the implementation of standardized test exams for educational study programs 50 items are consisting of three aspects namely the learning innovation model, statistical tests and ICT tests. The distribution of the test items is a learning innovation model of 20 test items, 10 item test statistics and 20 test item ICT items. Meanwhile, the number of questions for noneducational majors is 30 items consisting of two test aspects namely statistics and ICT. Statistical tests totaled 10 test questions and ICT totaled 20 test questions. The time given for working on standardized test questions for educational study programs is 50 minutes and for non-medical 40 minutes.

Over time, program evaluations are always carried out so that the number of test questions is changed to 30 questions for educational study programs and 20 questions for non-education. By distributing the test items is a learning innovation model of 10 test items, statistics of 5 test items and ICT for 15 test items. Whereas for non-educational majors namely statistical tests there were 5 test questions and ICT totaled 15 test questions.

Furthermore, for the implementation of the 2019 standardized test examinations, the number of questions added was for the educational study program totaling 40 items and the non-educational study program totaling 20 questions. In this standardized test exam for educational majors coupled with pedagogical aspects. So the divisions are 10 aspects of learning innovation, 10 questions of statistics, 10 questions of ICT and 10 questions of pedagogic. As for the non-educational majors, the statistical aspect is 10 questions and the ICT aspect is 10 questions.

In carrying out standardized test examinations, students must pass in all three aspects of the education majors or two aspects of the non-educational majors. If there is one aspect of a standardized test that does not pass, then the student must repeat only those aspects that did not pass until the graduation score is obtained. Remedial can be done on a predetermined remedial schedule, by registering on the previous application. The impact that is obtained by students if they do not pass this standard test is that students will not be able to take their certificates.

Evaluation of the implementation of this standard test activity produced several things that could be used as input for the improvement of the implementation of the next test period. Among them are students who feel the standards are set too high for short processing time, students need a grid to prepare themselves optimally, students feel too light on standardized test questions so that many deceive them when answering questions. Besides, students find it difficult because the questions in the lesson have passed a long time, so they have difficulty in answering. For example in the statistical test, many students who are less concerned with this course, consider it trivial because they do not know its usefulness. Therefore, as input to lecturers in the future who can take this course are expected to be more reminiscent of the importance of statistics courses. It takes careful preparation, so students can pass the standardized test exams imposed at Universitas Negeri Medan. 


\section{Conclusion}

The conclusions obtained from all of these explanations obtained information that the implementation of standardized test exams at Universitas Negeri Medan has proceeded according to the procedure. Regarding the facilities and infrastructure for carrying out standardized tests, exams have also been fulfilled. Shortcomings in the implementation have also been resolved properly.

\section{References}

[1] P. R. Indonesia, "Undang-undang Republik Indonesia nomor 20 tahun 2003 tentang sistem pendidikan nasional," Jakarta Pemerintah Republik Indones., 2003.

[2] D. P. Nasional, "Panduan Analisis Butir Soal," Jakarta: Depdiknas, 2008.

[3] Sugiyono, "Metode Penelitian Kuantitatif Kualitatif dan R \& D," Bandung Alf., 2014.

[4] Sugiyono, "Metode Penelitian Kombinasi," Bandung Alf., pp. 193, 305, 2011. 